\title{
The Bangkok Housing Market: Past Performance And Future Prospects
}

\author{
Pairote Srivarasat, Asian Institute of Technology, Thailand
}

Winai Wongsurawat, Mahidol University, Thailand

\begin{abstract}
This paper provides an overview of the evolution of the housing market in Bangkok beginning in the boom period of the 1990s up to the most recent developments. Key summary data are provided and a simple model of housing supply is developed. While the market has recovered from its biggest crisis, there remain future challenges, some of which are likely to present themselves in other countries as well. The influence of Chinese investment and the risk of capital flight represent medium-term threats. In the long term, an aging population and growing income and wealth inequality are likely to impede prospects for broad-based growth in housing demand.
\end{abstract}

Keywords: Thailand; Housing; Financial Crisis; Real Estate Bubble

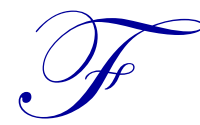

ounded in 1782 as the capital of Siam, Bangkok is today Thailand's largest metropolis and home to close to ten million people. As the capital of the second largest economy in South East Asia (behind only that of Indonesia), Bangkok is a thriving center of commerce and tourism. It is the world's most visited city, according to MasterCard's Global Destination Cities Index, with over twenty million foreign visitors in 2018 (MasterCard, 2018).

This paper provides an overview of the evolution of the housing market in Bangkok beginning from the boom period of the 1990s, continuing through the recovery and up to the most recent developments. After a presentation of key summary data, a simple model of housing supply is developed. Recent policy changes affecting the housing market will be discussed. Finally, an analysis of the prospects for the medium and long term development of the market will be presented.

\section{THE BANGKOK HOUSING MARKET - THE RECENT PAST}

Bangkok real estate experienced its largest boom in the early 1990s. In the first half of the decade, Thailand's GDP, fueled by foreign investment and financial liberalization, was growing at double digits and the stock market was experiencing a phenomenal boom. By the mid-1990s, almost two hundred thousand new units were being added to the market each year (see figure 1), a quantity that far exceeded residential demand ${ }^{1}$. Rapid capital flight ended the boom, resulting in a debt crisis and massive devaluation of the Thai currency. Economic panic spread through the region. The years following the 1997 Asian Financial Crisis saw the supply of new units in Bangkok fall by three quarters and annual average prices dropped by close ten percent at the trough.

The performance of the housing market in the decades following the crisis represents a mixed bag. Subsequent to a partial recovery in the early 2000s, growth in prices slowed down and turned negative in 2009 subsequent to the Global Financial Crisis. Historic floods that devastated Thailand's central plains in 2011 dampened the supply of new units, contributing to strong price growth in the following years. However, political instability, prolonged protests on the streets of Bangkok, and a military coup d'et at in 2014 stifled the market recovery. The current political climate remains uncertain with the first elections since the coup tentatively scheduled for March 2019.

\footnotetext{
${ }^{1}$ In this paper, new units are defined as completed and registered housing units (both houses and condominiums) built by developers and owners. The geographical focus is the Bangkok Metropolitan Region, which includes Bangkok and the surrounding provinces of Nonthabuuri, Pathumthani,
} Samut Prakan, Samut Sakhon and Nakhon Pathom. 
Figure 1. Number of new units in Bangkok and its vicinities, and annual price increases

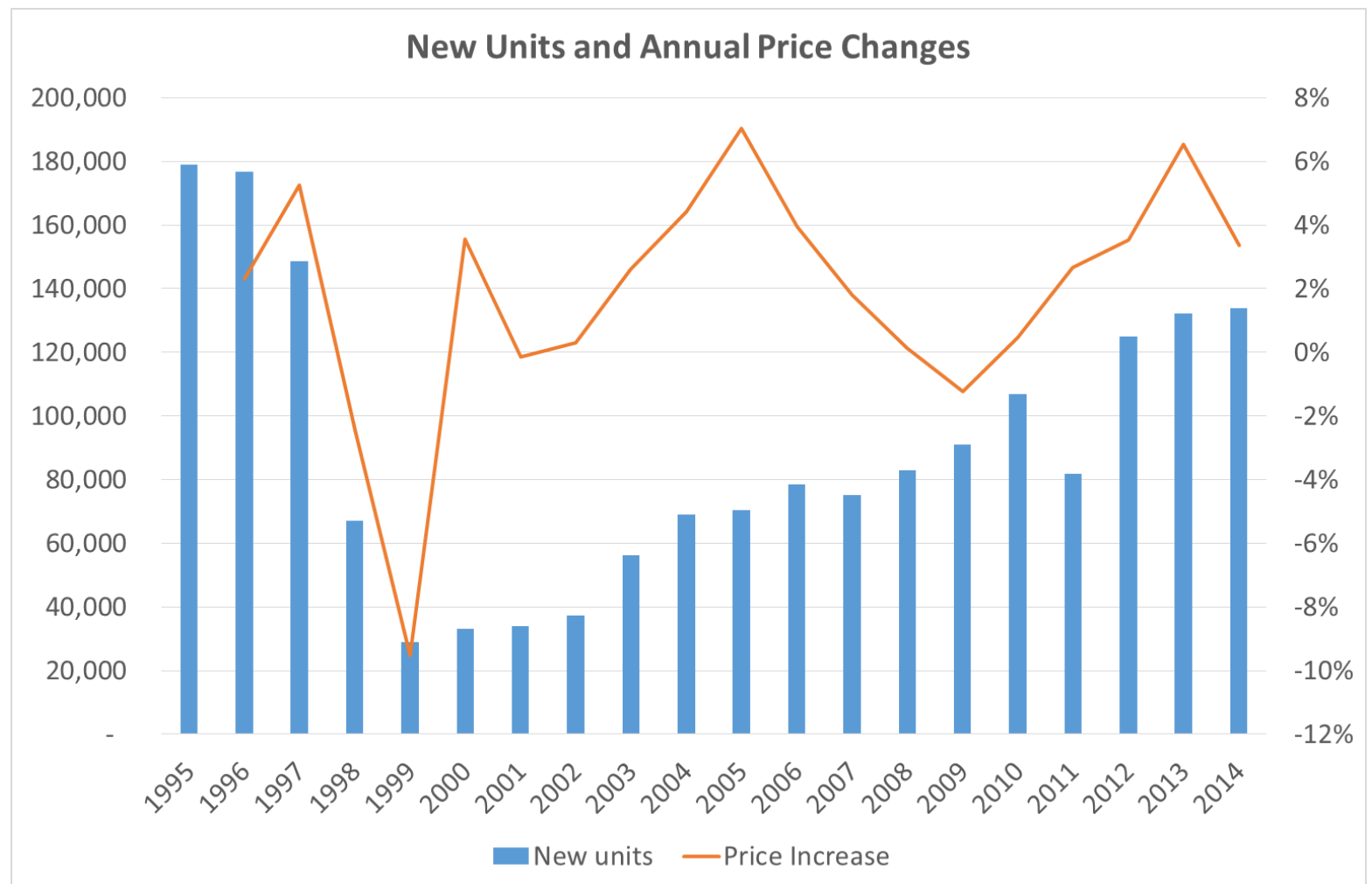

Source: New units: Bangkok District Offices, Municipal and Provincial Offices in the vicinities, Department of Land, Real Estate Information Center; Housing price index: Government Housing Bank and Real Estate Information Center

\section{MARKET STRUCTURE}

The dynamics of the housing market reflects the interaction between households (the demand side) and private developers (the supply side). Financial institutions, both private and government-owned banks, play an important intermediary role in the large financial transaction between the two sides of the market. While the Thai government plays a minor role in the development of housing projects ${ }^{2}$, it can influence the market in at least two ways. First, it can stimulate more lending through the Government Housing Bank and the Government Savings Bank, two major players in the market for home loans (Kritayanavaj, 2010).

Looking at historical data, the supply of mortgages shows an overall increasing trend since the 1997 crisis. By 2014, the annual number of new loans was approaching six hundred thousand. Interest rates have stayed low and relatively stable. The Minimum Loan Rate (MLR), the lending rate per annum that banks charge their prime major customers on term loans, has fluctuated in the range of five to eight percent in the recent years. See figure 2 for more information.

\footnotetext{
${ }^{2}$ As opposed to Singapore, where 80 percent of housing is government built (Economist, 2017). 
Figure 2. The number of mortgages and the minimum lending rate (MLR)

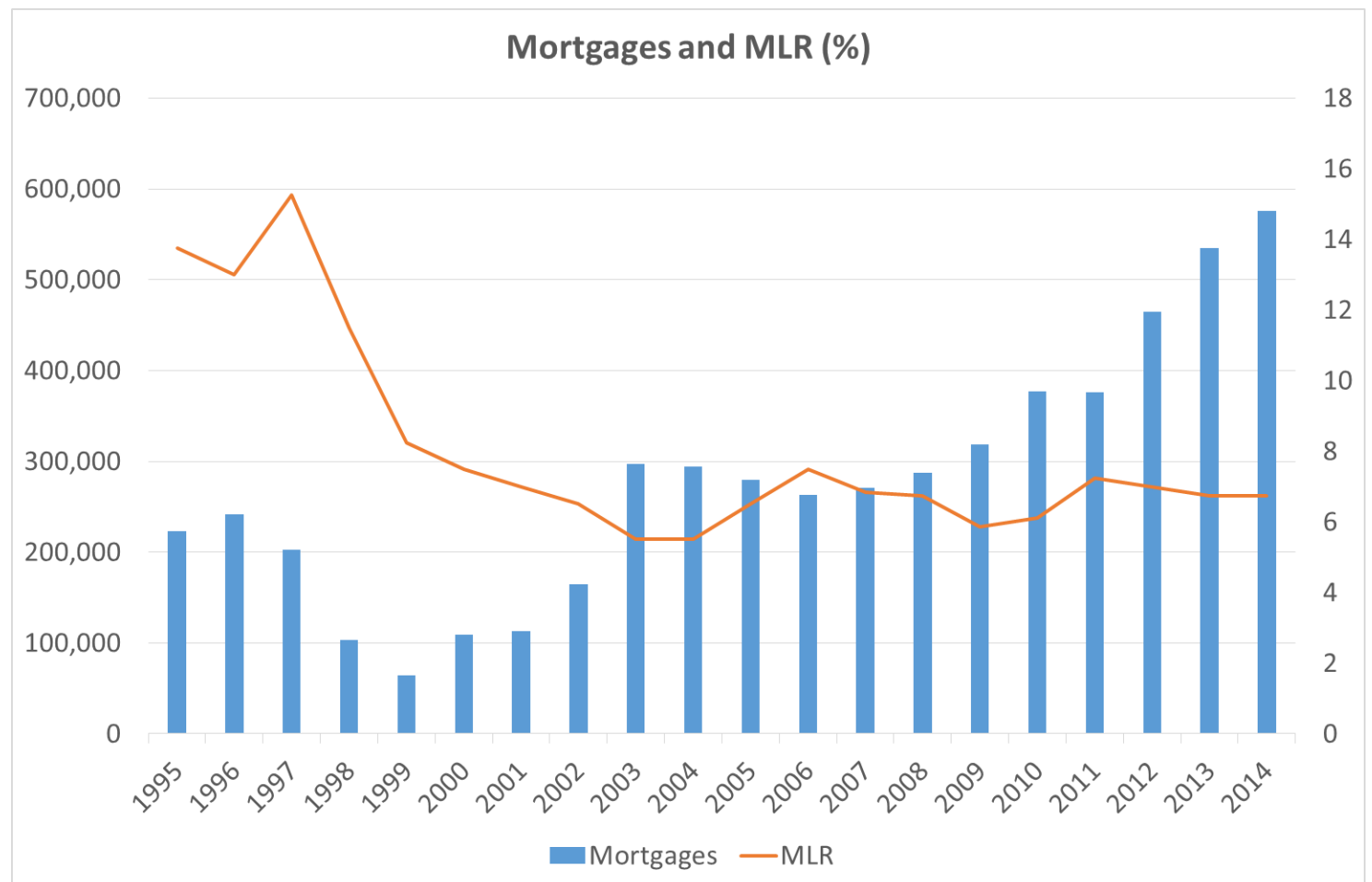

Source: Loans: Bank of Thailand, Government Housing Bank, National Housing Authority, Real Estate Information Center; Minimum Loan Rate (MLR): Bank of Thailand and Government Housing Bank

The second way the government can sway decisions of housing developers and buyers is through policies on tax incentives/deductions (for both sellers and buyers) and investments in infrastructure. Indeed, one of the biggest recent boons for urban real estate development has been the construction and extension of Bangkok Mass Transit System (better known as the BTS sky train). As location is the prime criteria most condominium buyers have in mind (Bangkok is notorious for its rush-hour traffic jams), high price condominiums along the BTS routs have been received by the market with great fanfare and immediately sell out without fail.

A host of other internal and external factors also exert significant influence on the housing market. Macroeconomic conditions stoke buyer and seller sentiments. Fluctuations in economic growth and inflation result in changes in interest rates, which can encourage or discourage home purchases. Figure 3 shows the relationship between the natural logarithm of new housing units and the natural logarithm of Thailand's real GDP (in billions of Thai baht). Excluding the boom years (1995 through 1998), GDP and new housing supply are tightly correlated. An ordinary least squares regression suggests that a one percent increase in real GDP is associated with approximately two and a half percent annual growth in new housing units. Details of the regression are given in figure 3 and table 1 . 
Figure 3. Economic growth and housing supply

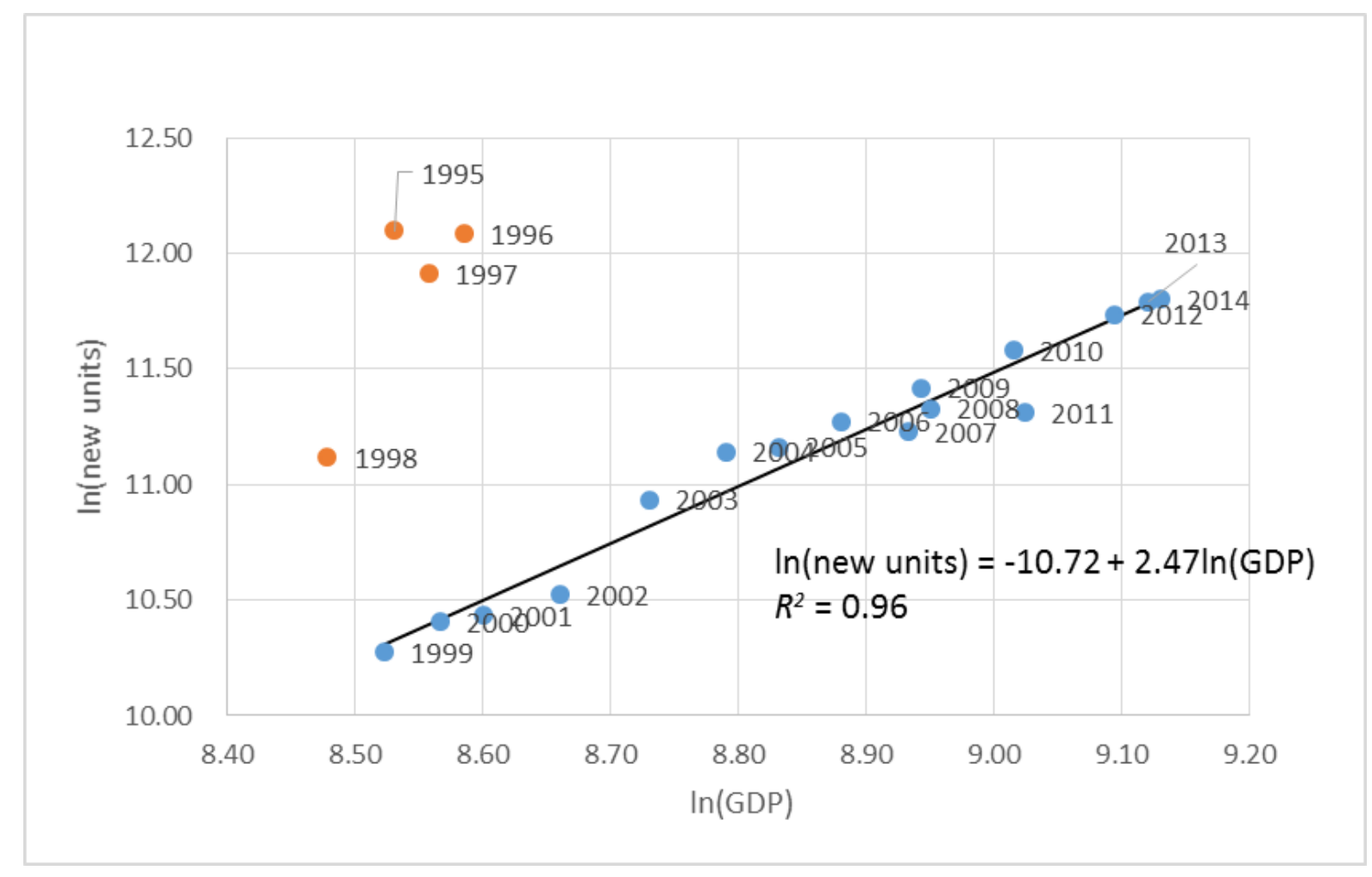

Table 1. Regression of new housing units on real GDP (both in log form)

\begin{tabular}{|c|c|c|c|c|c|}
\hline \multicolumn{6}{|c|}{ Regression Statistics } \\
\hline Multiple R & 0.980 & & & & \\
\hline $\mathrm{R}^{2}$ & 0.960 & & & & \\
\hline Adjusted $\mathrm{R}^{2}$ & 0.957 & & & & \\
\hline Standard Error & 0.104 & & & & \\
\hline Observations & 16 & & & & \\
\hline \multicolumn{6}{|c|}{ ANOVA } \\
\hline & $d f$ & SS & $M S$ & $\boldsymbol{F}$ & Significance $F$ \\
\hline Regression & 1 & 3.636 & 3.636 & 333.883 & 0.000 \\
\hline Residual & 14 & 0.152 & 0.011 & & \\
\hline \multirow[t]{2}{*}{ Total } & 15 & 3.788 & & & \\
\hline & Coefficients & Standard Error & t Stat & P-value & \\
\hline Intercept & -10.725 & 1.197 & -8.958 & 0.000 & \\
\hline Real GDP & 2.468 & 0.135 & 18.272 & 0.000 & \\
\hline
\end{tabular}

Because Thailand is an open economy highly dependent on exports and tourism, developments outside the country can also impact the domestic housing market both indirectly (through GDP growth) and directly (through real estate demand from foreign investors) as will be discussed in more detail later.

Figure 4 summarizes the housing market structure described above. 
Figure 4. The housing market structure

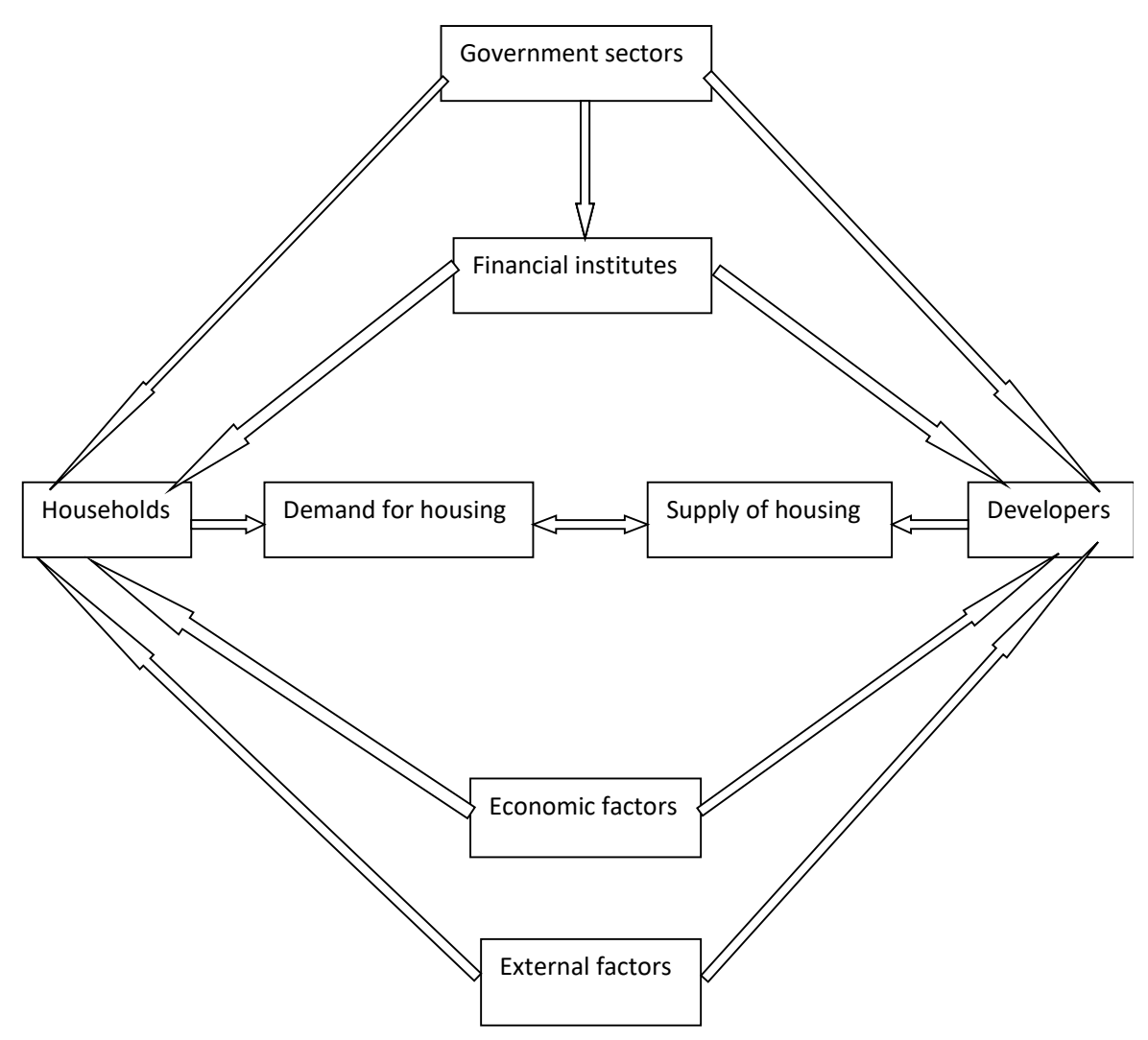

Source: Author's conceptualization

\section{A NEW LAND AND PROPERTY TAX}

A new Land and Property Tax has been passed coming into effect in January 2019. Accordingly, residential property could be taxed up to as much as $0.5 \%$ of the appraised value, while the ceiling for commercial property is set at $2 \%$ (see table 2 for partial details).

The new tax will increase the cost of home ownership, especially for high-value property and second or third homes. In the long run, elevated cost of ownership will push up rents as markets adjust to the higher costs of ownership (Himmelberg, Mayer \& Sinai, 2005).

The effect of the new tax on commercial property will be even more interesting, as the rates are set significantly higher than those for residential property. Rents on luxury condominiums in prime locations are expected to increase to reflect escalating costs. The upward pressure on rents in non-prime locations could be tempered by the landlords' compulsion to rent out their property. In the long run, the supply of residential and commercial units is expected to rise, as the unused/vacant land will be taxed at a rate of $1-3 \%$, with an increase of $0.5 \%$ every three years until the rate reaches a maximum of $5 \%$. 
Table 2. Partial details of the new Land and Building Tax coming into effect in January 2019

\begin{tabular}{|c|c|c|c|c|c|}
\hline & \multicolumn{2}{c}{$\begin{array}{c}\text { Residential } \\
\text { (Ceiling .5\%) }\end{array}$} & \multicolumn{2}{c|}{$\begin{array}{c}\text { Commercial } \\
\text { (Ceiling 2\%) }\end{array}$} \\
\hline \multicolumn{2}{|c|}{$\mathbf{1}^{\text {st }}$ home } & \multicolumn{2}{c|}{$\mathbf{2}^{\text {nd }}$ home } & \multicolumn{3}{c|}{ Tax rate } \\
\hline Appraised value & Tax rate & Appraised value & Tax rate & Appraised value & $.3 \%$ \\
\hline$<50 \mathrm{~m}$ & Exempt & $<5 \mathrm{~m}$ & $.03 \%$ & $<20 \mathrm{~m}$ & $.5 \%$ \\
\hline $50-100 \mathrm{~m}$ & $.05 \%$ & $5-10 \mathrm{~m}$ & $.05 \%$ & $20-50 \mathrm{~m}$ & $.7 \%$ \\
\hline$>100 \mathrm{~m}$ & $.10 \%$ & $10-20 \mathrm{~m}$ & $.10 \%$ & $50-100 \mathrm{~m}$ & $.9 \%$ \\
\hline & & $20-30 \mathrm{~m}$ & $.15 \%$ & $100 \mathrm{~m}-1 \mathrm{bn}$ & $1.2 \%$ \\
\hline & & $30-50 \mathrm{~m}$ & $.20 \%$ & $1-3 \mathrm{bn}$ & $1.5 \%$ \\
\hline
\end{tabular}

Source: Thaiturapaisan (2017)

\section{MEDIUM TERM RISK - FOREIGN INVESTMENT}

Chinese tourists, over the recent past, have grown to become the dominant group of visitors to Thailand, thanks to the China's rapidly emerging middle class. By 2018, it is estimated that Chinese investors were responsible for roughly fourteen percent of new condominium demand in Bangkok (Hoijan, 2018). Chinese buyers purchased condominiums for home sharing or as investment. As Thai universities open new international programs catering to foreign students, Chinese parents' are increasingly sending their children to study in Thailand. It is becoming increasingly common for Chinese parents to purchase condos for their sons and daughters to live in while studying aboard. Such a large and growing portion of housing demand from foreign investors can represent a significant risk, as it can evaporate quickly and unexpectedly.

With the forecasted slowdown of the Chinese economy, jitters among real estate developers have begun to appear. A series of unfortunate events, including a boat carrying Chinese tourist capsizing in Phuket and a video clip showing a security guard in a Thai airport beating a Chinese traveler, has resulted in a plunge in the number of visitors from the mainland (Thangthong-Knight, 2018). In late 2018, the Bank of Thailand enacted new regulation requiring a bigger down payment for second and third homes (Thaichareon \& Sriring, 2018). The regulation is thought to be a partial safeguard against the risk of massive default on mortgage contracts by foreign buyers, many with minimal down payments.

\section{LONG TERM CHALLENGES - DEMOGRAPHICS AND INEQUALITY}

Thailand's low birthrate presents a long-term challenge for the housing market. Thai Universities whose seats used to be fiercely competed for, now find themselves with excess capacity (Kamnuansilpa, 2018). A declining demographic trend does not bode well for the housing market in the decades to come. Japan, a country further down the agingsociety road than Thailand, is now struggling to cope with abandoned houses that are being offered by local governments to any takers for free (Jozuka, 2018). Property developers and policy makers must prepare for such longterm challenges, although the issue will first become serious in rural areas of the country.

Yet another long-term challenge for Thailand's housing market is the country's growing income and wealth inequality. A recent study by Credit Suisse ranked Thailand among the most unequal societies in the world in terms of wealth distribution (Bangkok Post, 2018). According to the report, in 2018 the top one percent owned a whopping two thirds of the country's wealth! The shrinking purchasing power of the majority of buyers will eventually imply smaller room for growth in the housing market. Recent political developments leading the country down an autocratic rule suggest there is little chance that the government will enact strong policies to address the growing inequality problem.

\section{CONCLUDING REMARKS}

Studying Bangkok's housing market yields valuable lessons for real estate development in the emerging economies. The boom and bust in the 1990s warn of the dangers from speculative bubbles and irrational exuberance. While the market has recovered from its biggest crisis, there remain future challenges, a few of which are likely to also present 
themselves in other countries. The influence of Chinese investment and the risk of capital flight present medium-term threats. In the long term, an aging population and growing income and wealth inequality are likely to impede prospects for broad-based growth in housing demand.

\section{AUTHOR BIOGRAPHIES}

Pairote Srivarasat is a career banker with decades of experience in home loans. He has served on academic committees for real estate research projects and is currently a doctoral candidate at the School of Management, Asian Institute of Technology, Thailand. Email: srivarasat@hotmail.com

Winai Wongsurawat is an assistant professor at the College of Management, Mahidol University, Thailand. Email: winai.won@mahidol.ac.th

\section{REFERENCES}

Bangkok Post. (2018, December 6). Thailand most unequal country in 2018. Retrieved from: https://www.bangkokpost.com/business/news/1588786/report-thailand-most-unequal-country-in-2018

Economist (2017, July 6). Why $80 \%$ of Singaporeans live in government-built flats. Retrieved from: https://www.economist.com/asia/2017/07/06/why-80-of-singaporeans-live-in-government-built-flats

Himmelberg, C., Mayer, C. and Sinai, T. (2005). Assessing High House Prices: Bubbles, Fundamentals and Misperceptions. Journal of Economic Perspectives, 19 (4): 67-92.

Hoijan, A. (2018, December 15). Beware! Chinese investors default may burst Thailand's real estate bubble (in Thai). Retrieved from: https://www.thebangkokinsight.com/75473/

Jozuka, E. (2018, December 18). Japan has so many vacant homes it's giving them away. CNN. Retrieved from: https:/edition.cnn.com/2018/12/05/asia/japan-vacant-akiya-ghost-homes/index.html

Kamnuansilpa, P. (2018, September 20). The existential threat to Thai universities. The Nation. Retrieved from: http://www.nationmultimedia.com/detail/opinion/30354844

Kritayanavaj, B. (2010). An example of a Real Estate Market Observatory: Thailand. 4th Global Conference on Housing Finance in Emerging Markets, May 26-27, 2010, Washington, D.C. Retrieved from http://siteresources.worldbank.org/FINANCIALSECTOR/Resources/Session2-BallobhKritayanavaj.pdf

MasterCard (2018, September 25). Big Cities, Big Business: Bangkok, London and Paris Lead the Way in Mastercard's 2018 Global Destination Cities Index. Retrieved from https://newsroom.mastercard.com/press-releases/big-cities-big-businessbangkok-london-and-paris-lead-the-way-in-mastercards-2018-global-destination-cities-index/

Thaichareon, K. and Sriring, O. (2018, October 4). Thailand to require minimum down payments to contain bad property loans. Reuters. Retrieved from: https://www.reuters.com/article/thailand-economy-mortgages/update-1-thailand-to-requireminimum-downpayments-to-contain-bad-property-loans-idUSL4N1WK1OL

Thaiturapaisan, T. (2017, April 19). The impact of new Land and Building Tax Law on Thai property developers. SCB Economic Intelligence Center. Retrieved from: https://www.scbeic.com/en/detail/product/3443

Thangthong-Knight, R. (2018, October3). Thailand disturbed by sharp decline in Chinese tourists, turned off by series of unfortunate events. South China Morning Post. Retrieved from: https://www.scmp.com/magazines/postmagazine/travel/article/2166804/thailand-disturbed-sharp-decline-chinese-tourists 


\section{NOTES}

